Jurnal Penelitian, Vol. 10, No. 2, Agustus 2016

\title{
PRODUK KEGIATAN USAHA PERBANKAN SYARI'AH DALAM MENGEMBANGKAN UMKM DI ERA MASYARAKAT EKONOMI ASEAN (MEA)
}

\author{
Santoso dan Ulfah Rahmawati \\ Universitas Islam Sultan Agung Semarang \\ santos00583@gmail.com
}

\begin{abstract}
Economic life is at first simple. Activities of production, consumption and distribution is very simple. Along with the times, human population increased so that the economic activities also increased. One of government efforts to welcome the Syariah Economic Community and improve the performance of Micro, Small and Medium Enterprises is their growth of conducive business climate conducted by the central government and local governments to establish legislation and policy. The problem often faced by each UMKM is not apart from the need for funds to finance their business. To meet their needs, almost all UMKM utilized banking like the Islamic bank. Islamic bank is a financial institution that serves as an intermediary for the excess funds to parties who lack funds for operations and other activities in accordance with Islamic law that funds in the form of financing, such as mudaraba financing, Musharaka financing and murabaha financing. Financing has been distributed by Islamic banks to contain the risk of congestion callable, so it can affects the bottom line.
\end{abstract}

Keywords: Sharia Banking, UMKM, Asean Economic Community. 


\begin{abstract}
Abstrak
Kehidupan ekonomi pada mulanya masib bersifat sederhana. Kegiatan produksi, konsumsi dan distribusi yang dilakukan pun masib sangat sederhana. Seiring dengan perkembangan zaman, populasi manusia mengalami pertumbuhan sehingga kegiatan ekonomi yang ada juga mengalami peningkatan. Salab satu bentuk upaya pemerintah dalam menyambut Masyarakat Ekonomi Syariah (MEA) dan meningkatkan kinerja Usaha Mikro Kecil dan Menengah (UMKM) adalab adanya penumbuban iklim usaha yang kondusif dilakukan oleh pemerintah dan pemerintah daerah dengan menetapkan peraturan perundang-undangan dan kebijakan. Masalah yang sering dihadapi oleb setiap UMKM yaitu tidak terlepas dari kebutuhan akan dana untuk membiayai usahanya. Untuk memenubi kebutubannya, hampir semua UMKM memanfaatkan perbankan salah satunya adalah bank syariah. Bank syariah adalah suatu lembaga keuangan yang berfungsi sebagai perantara bagi pihak yang berlebihan dana dengan pibak yang kekurangan dana untuk kegiatan usaba dan kegiatan lainnya sesuai dengan bukum Islam yang menyalurkan dana dalam bentuk pembiayaan, diantaranya adalah pembiayaan mudharabah, pembiayaan musyarakah, dan pembiayaan murabahah. Pembiayaan yang telah disalurkan oleh bank syariah mengandung risiko kemacetan pelunasannya, sehingga dapat berpengarub terhadap laba.
\end{abstract}

Kata Kunci: Perbankan Syariah, UMKM, Masyarakat Ekonomi ASE AN.

\title{
A. Pendahuluan
}

Bank Syari'ah memiliki kewajiban untuk memastikan keabsahan produk dan jasa yang ditawarkan sesuai dengan prinsip-prinsip syari'ah, begitu juga dengan operasional yang dijalankan. Sebenarnya, hal ini merupakan kewajiban dan tanggung jawab dari dewan pengawas syari'ah. Dewan pengawas syariah memiliki tugas untuk memastikan bahwa berbagai bentuk transaksi yang diterapkan bank Islam harus dipastikan kesesuaiannya dengan prinsip syari'ah. ${ }^{1}$

Di timur tengah untuk memastikan keislaman dari

${ }^{1}$ Trisadini P. Usanti, Abd. Shomad, Transaksi Bank Syariah, (Jakarta: Bumi Aksara, 2013), hlm. 87. 
perbankan Islam adalah adanya Badan Pengawas Agama (Religious Supervisory Board- RSB). Bank-bank Islam menggunakan para sarjana hukum Islam dalam kapasitasnya sebagai konsultan dan penasihat untuk menelaah kontrak, perjanjian, dan transaksinya. Hal ini untuk memastikan bahwa aktivitas sehari-hari bank-bank Islam adalah area dari mobilisasi dan alokasi sumber daya yang sesuai dengan syari'ah. Sedangkan di Malaysia yang menjamin bahwa operasional bank Islam sesuai dengan prinsip syariah adalah Shariah Supervisory Board (SBB), Sudin Haron menjelaskan bahwa:

"A Shariah Supervisory Board (SBB) is a body established under a specific or general statute of an Islamic bank of a particular country with the main objective of ensuring that the operations of the bank are not violating any syariah principles. In other words, the board has the responcibility to ensure that, firstly, the banking products and services offered to customers are in accordance with shariah; secondly, the investments or projects in which the bank is engaged are permissible by Shariah; and finally the bank itself is managed according to Islamic principles". ${ }^{2}$

Pertumbuhan perekonomian yang bernafaskan Islam akhir-akhir ini mendapatkan sambutan hangat dari masyarakat Indonesia. Hal ini dibuktikan dengan semakin banyaknya lembaga keuangan yang berlabelkan Islam (syari'ah) seperti: BRI Syari'ah, BNI Syari'ah, Bank Jateng Syari'ah, Bank Syari'ah Mandiri, BII Syari'ah, Bank Mu'amalat, Bank Danamon Syari'ah, BPRS Suriyah dan tentunya masih banyak lagi lembaga keuangan yang bernafaskan Islam dalam melaksanakan dan mengoperasikan lembaga keuangan tersebut.

Menurut data Bank Indonesia, tingkat perkembangan ekonomi syari'ah ini dapat dilihat dari jumlah institusi perbankan syari'ah yang tumbuh dan berkembang pada kurun waktu dua periode terakhir. Pada tahun 1989 - 1999 hanya ada 2 Bank Umum Syari'ah (BUS), 1 Unit Usaha Syari'ah (UUS) dan 79 BPRS dengan aset masih berkisar 1.5 triliun. Sedangkan pada kurun waktu 2000 - 2010 hingga bulan Januari 2011, jumlah

${ }^{2}$ Ibid., hlm. 88. 
institusi perbankan syari'ah telah menjadi 11 BUS, 23 UUS, 151 BPRS dengan aset mencapai 95 triliun plus $745 \mathrm{M}^{3}$

Perkembangan ekonomi syari'ah di tanah air semakin menggeliat dan terus diminati banyak kalangan. Bukan hanya dari kalangan muslim, bahkan kalangan non-muslim pun sekarang banyak melirik ekonomi syariah sebagai alternatif dalam aktifitas perkonomian mereka. Indonesia dapat dikatakan cukup ketinggalan dalam mengembangkan ekonomi syari'ah jika dibanding negara-negara berpenduduk muslim lainnya, seperti Malaysia dan lain-lain.

\section{B. Pembahasan}

\section{Pengertian Bank Syari'ah}

Bank syari'ah terdiri atas dua kata, yaitu (a) bank, dan (b) syari'ah. Kata bank bermakna suatu lembaga keuangan yang berfungsi sebagai perantara keuangan dari dua pihak, yaitu pihak yang berlebihan dana dan pihak yang kekurangan dana. Kata syari'ah dalam versi syari'ah di Indonesia adalah aturan perjanjian berdasarkan yang dilakukan oleh pihak bank dan pihak lain penyimpangan dana dan/atau pembiayaan kegiatan usaha dan kegiatan lainnya sesuai dengan hukum Islam.

Penggabungan kedua kata dimaksud, menjadi "bank syari'ah". Bank syari'ah adalah suatu lembaga keuangan yang berfungsi sebagai perantara bagi pihak yang berkelebihan dana dengan pihak yang kekurangan dana untuk kegiatan usaha dan kegitan lainnya sesuai dengan hukum Islam. Selain itu, bank syari'ah biasa disebut Islamic banking atau interest fee banking, yaitu suatu sistem perbankan dalam pelaksanaan operasional tidak menggunakan sistem bunga (riba), spekulasi (maisir), dan ketidakpastian atau ketidakjelasan (gharar). ${ }^{4}$

Kata bank dari kata banque dalam bahasa Prancis, dan dari banco dalam bahasa Italia, yang berarti peti/lemari atau

${ }^{3}$ Nevi Hesnita, "Politik Hukum Ekonomi Syariah di Indonesia", Jurnal, IAIN Ar-Raniry, 2012, hlm. 259-260.

${ }^{4}$ Zainuddin Ali, Hukum Perbankan Syariah, (Jakarta: Sinar Grafika, 2010), hlm. 1. 
bangku. Kata peti atau lemari menyiratkan fungsi sebagai tempat menyimpan benda-benda berharga, seperti peti emas, peti berlian, peti uang dan sebagainya. Dalam al-Qur'an, istilah bank tidak disebutkan secara eksplisit. Tetapi jika yang dimaksud adalah sesuatu yang memiliki unsur-unsur seperti struktur, manajemen, fungsi, hak dan kewajiban maka semua itu disebut dengan jelas, seperti zakat, sadaqah, ghanimah (rampasan perang), bai' (jual beli), dayn (utang dagang), maal (harta) dan sebagainya, yang memiliki fungsi yang dilaksanakan oleh peran tertentu dalam kegiatan ekonomi.

Pada umumnya yang dimaksud dengan bank syari'ah adalah lembaga keuangan yang usaha pokoknya memberikan kredit dan jasa-jasa lain dalam lalu lintas pembayaran serta peredaran uang yang beroperasi disesuaikan dengan prinsipprinsip syari'ah. Oleh karena itu, usaha bank akan selalu berkaitan dengan masalah uang sebagai dagangan utamanya.

Kegiatan dan usaha bank akan selalu berkait dengan komoditas antara lain:

a. Pemindahan uang,

b. Menerima dan membayarkan kembali uang dalam rekening koran,

c. Mendiskonto surat wesel, surat order maupun surat surat berharga lainnya,

d. Membeli dan menjual surat surat berharga,

e. Membeli dan menjual cek wesel, surat wesel, kertas dagang,

f. Member kredit, dan

g. Memberi jaminan kredit. ${ }^{5}$

\section{Dasar Hukum Bank Syari'ah}

Bank syari'ah secara yuridis normatif dan yuridis empiris diakui keberadaannya di negara Republik Indonesia. Pengakuan secara yuridis normatif tercatat dalam peraturan perundang undangan di Indonesia, di antaranya, Undang - Undang No.

${ }^{5}$ Heri Sudarsono, Bank dan Lembaga Keuangan Syariah (Deskripsi dan Ilustrasi), (Yogyakarta: Ekonisia, 2013), hlm. 29. 
7 Tahun 1992 tentang Perbankan, Undang - Undang No. 10 tentang Perubahan atas Undang - Undang No. 7 Tahun 1998 tentang Perbankan, Undang - Undang No. 3 Tahun 2004 tentang Perubahan atas Undang - Undang No. 23 Tahun 1999 tentang Bank Indonesia, Undang - Undang No. 3 Tahun 2006 tentang Perubahan Atas Undang - Undangan No. 7 Tahun 1989 tentang Peradilan Agama. Selain itu, pengakuan secara yuridis empiris dapat dilihat perbankan syariah tumbuh dan berkembang pada umumnya di seluruh Ibukota provinsi dan Kabupaten di Indonesia, bahkan beberapa bank konvensional dan syari'ah keuangan lainnya membuka unit usaha syariah (bank syari'ah, asuransi syari'ah, pegadaian syari'ah, dan semacamnya). Pengakuan secara yuridis dimaksud, memberi peluang tumbuh dan berkembang secara luas kepada bank umum (konvensional) untuk membuka kantor cabang yang khusus melakukan kegiatan usaha berdasarkan prinsip syari'ah. ${ }^{6}$

Perkembangan industri perbankan syari'ah di Indonesia tidak hanya sampai di sini, masih terdapat beberapa hal yang harus terus diperbaiki dan dikembangkan lebih lanjut sebagai tantangan perbankan syari'ah ke depan di antaranya sebagai berikut:

a. Kepastian hukum tentang mekanisme penyelesaian sengketa.

UU Perbankan Syariah belum memuat secara pasti mekanisme penyelesaian sengketa yang dapat terjadi antara nasabah dan bank syariah terutama mengenai lembaga peradilan yang bertanggung jawab mengurus tentang sengketa tersebut.

b. Batasan yang jelas antara peran BI dan DSN MUI.

Perlu kejelasan lebih lanjut dalam pembagian tugas antara BI dan DSN MUI dalam perbankan syari'ah di Indonesia. Kejelasan ini perlu agar tidak terjadi benturan kewenangan pada saat UU Perbankan Syari'ah diberlakukan.

${ }^{6}$ Zainuddin Ali, Hukum Perbankan Syariah, (Jakarta: Sinar Grafika, 2010), hlm. 2 . 
c. Peningkatan kualitas sumber daya insan perbankan syari'ah Indonesia.

Saat ini SDI yang dimiliki bank syari'ah kurang memadai yang memiliki kompetensi yang tidak hanya di bidang perbankan, tetapi mencakup pula aspek syari'ahnya dalam praktek perbankan. ${ }^{7}$

Lahirnya UU tersebut akan menguji sejauh mana pelaku perbankan syari'ah bisa mengakselerasi peningkatan kualitas kerjanya dalam membangun perekonomian nasional setelah memiliki payung hukum. Jika beberapa waktu lalu beralasan belum memiliki payung hukum sehingga tidak bisa bergerak leluasa atau ragu bergerak, kini setelah disahkannya UU itu diharapkan keraguan itu tidak ada lagi, sehingga secara komersial maupun sosial bisa bergerak dengan leluasa sesuai dengan ketentuan hokum yang berlaku dalam membangun perekonomian nasional.

Sesuai dengan paparan di atas, lahirnya UU Perbankan Syari'ah membuka kesempatan lebih besar untuk mendorong akselerasi perkembangan bank syari'ah ke depan. ${ }^{8}$

\section{Sejarah Perkembangan Bank Syari'ah}

Sejarah, awal mula kegiatan Bank Syari'ah yang pertama kali dilakukan adalah di Pakistan dan Malaysia pada sekitar tahun 1940an. Kemudian di Mesir pada tahun 1963 berdiri Islamic Rural Bank di desa It Ghamr Bank. Bank ini beroperasi di pedesaan Mesir dan masih berskala kecil.

Di Uni Emirat Arab, baru tahun 1975 dengan berdiri Dubai Islamic Bank. Kemudian di Kuwait pada tahun 1977 berdiri Kuwait Finance House yang beroperasi tanpa bunga. Selanjutnya kembali di Mesir pada tahun 1978 berdiri Bank Syari'ah yang diberi nama Faisal Islamic Bank. Langkah ini kemudian diikuti oleh Islamic International Bank for Invesment and Development Bank.

${ }^{7}$ Amir Machmud dan Rukmana, Bank Syariah (Teori, Kebijakan, dan Studi Empiris di Indonesia, (Jakarta: Erlangga, 2010), hlm. 76.

${ }^{8}$ Ibid,. 
Di Siprus tahun 1983 berdiri Faisal Islamic Bank of Kibris. Kemudian di Malaysia Bank Syari'ah lahir tahun 1983 dengan berdirinya Bank Islam Malaysia Berhad (BIMB) dan pada tahun 1999 lahir pula Bank Bumi Putera Muamalah.

Di Iran sistem perbankan syari'ah mulai berlaku secara nasional pada tahun 1983 sejak dikeluarkannya undang-undang perbankan Islam. Kemudian di Turki Negara yang berideologi sekuler bank syari'ah lahir tahun 1984 yaitu dengan hadirnya Daar al-Maal al-Islami serta Faisal Finance Institution dan mulai beroperasi tahun 1985 .

Salah satu negara pelopor utama dalam melaksanakan sistem perbankan syari'ah secara nasional adalah Pakistan. Pemerintah Pakistan mengkonversi seluruh sistem perbankan di negaranya pada tahun 1985 menjadi sistem perbankan syari'ah. Sebelumnya pada tahun 1979 beberapa institusi keuangan terbesar di Pakistan telah menghapus sistem bunga dan mulai tahun ini juga pemerintah Pakistan mensosialisasikan pinjaman tanpa bunga, terutama kepada petani dan nelayan. ${ }^{9}$

Kehadiran bank yang berdasarkan syariah di Indonesia masih relative baru, yaitu baru pada awal tahun 1990an, meskipun masyarakat Indonesia merupakan masyarakat muslim terbesar di dunia. Pra-karsa untuk mendirikan Bank Syari'ah di Indonesia dilakukan oleh Majelis Ulama Indonesia (MUI) pada tanggal 18-20 Agustus 1990.

Bank Syari'ah pertama di Indonesia merupakan hasil kerja perbankan MUI yaitu dengan dibentuknya PT. Bank Muamalat Indonesia (BMI) yang akte pendiriannya ditandatangani tanggal 1 November 1991. Bank ini ternyata berkembang cukup pesat sehingga saat ini BMI sudah memiliki puluhan cabang terbesar di beberapa kota besar seperti Jakarta, Surabaya, Bandung, Makasar dan kota lainnya. ${ }^{10}$

Dalam perkembangan selanjutnya kehadiran bank syari'ah di Indonesia khususnya cukup menggembirakan.

${ }^{9}$ Kasmir, Bank \& Lembaga Kenangan Lainnya, (Jakarta: RajaGrafindo Persada, 2002), hlm. 177-178.

${ }^{10}$ Ibid., hlm. 178-179. 
Disamping BMI, saat ini juga telah lahir Bank Syari'ah milik pemerintah seperti Bank Syari'ah Mandiri (BSM). Kemudian berikutnya berdiri Bank Syari'ah sebagai cabang dari bank konvensional yang sudah ada, seperti Bank BNI, Bank IFI dan BPD Jabar. Bank-bank Syari'ah lain yang direncanakan akan membuka cabang adalah BRI, Bank Niaga dan Bank Bukopin.

Kehadiran bank syari'ah ternyata tidak hanya dilakukan oleh masyarakat muslim, akan tetapi juga bank milik non muslim. Saat ini Bank Islam sudah tersebar di berbagai Negara-negara muslim dan non muslim, baik di benua Amerika, Australia dan Eropa. Bahkan banyak perusahaan keuangan dunia seperti ANZ, Chase Chemical Bank dan Citibank telah membuka cabang yang berdasarkan syariah. ${ }^{11}$

Upaya reformasi perbankan yang memberikan peluang lebih besar pada sistem perbankan syari'ah telah dilakukan di beberapa Negara. Di Arab Saudi, selain banyak berdiri bank Islam, juga diikuti oleh munculnya cabang-cabang syari'ah dari bank konvensional.

Bank NCB, misalnya, mulai membuka cabang syari'ahnya di Mekah dan Madinah, kemudian berkembang ke tempat-tempat lain. Dalam sistem ini, bagi hasil dihitung pada tiap-tiap cabang. Di Malaysia, selain kovensional dapat membuka Islamic window yang dipayungi oleh Skim Perbankan Tanpa Faedah (SPTF). Karena hanya bersifat window, dalam sistem ini, bagi hasil dihitung secara keseluruhan dari aktifitas SPTF yang dilakukan oleh bank-bank tersebut. Reformasi yang lebih luas dilakukan di Iran, yakni berlangsung dalam tiga tahap: restrukturisasi perbankan (1979-1982), adopsi sistem perbankan syariah ke dalam sistem perekonomian nasional yang dimulai sejak $1986 .{ }^{12}$

\section{Produk-produk Perbankan Syariah di Indonesia}

Pertumbuhan produk perbankan syari'ah dan lembaga keuangan syariahnya di negara Republik Indonesia, yang

${ }^{11}$ Ibid., hlm. 179.

${ }^{12}$ Adiwarman A. Karim, Ekonomi Islam (Suatu KAjian Kontemporer), (Jakarta: Gema Insani, 2007), hlm. 78. 
penduduknya mayoritas muslim, bahkan muslimnya terbesar di dunia, jauh tertinggal bila dibandingkan Amerika yang penduduk muslimnya sangat kecil. Produk syari'ah baru dikenal di Indonesia di awal 1990-an, yaitu ketika Bank Muamalat Indonesia berdiri. Berawal dari produk perbankan syari'ah, saat ini kaum muslimin Indonesia sudah dapat berinvestasi lewat berbagai bentuk investasi secara syari'ah, di antaranya akan diuraikan secara umum sebagai berikut. ${ }^{13}$

a. Pasar Modal

Jika investor ingin berinvestasi secara syari'ah di bursa saham, saat ini ada dua cara yang bisa ditempuh. Pertama, membuat portofolio tersendiri dengan mengacu pada daftar daham halal atau Jakarta Islamic Indek. (JII) yang dikeluarkan Majelis Ulama Indonesia. Namun, selama ini prestasi Jakarta Islamic Index masih underperform karena pasar modal yang lesu, sehingga peluang mencetak labanya kecil sekali, dan kedua, lewat reksadana syari'ah.

b. Reksadana Syari'ah

Dalam reksadana syari'ah, manajer investasi akan menanamkan dananya pada saham atau Ifixed income yang halal. Investor diperkenalkan pada investasi riil, bukan yang spekulatif. Reksadana syari'ah dimaksud, walaupun dilakukan secara syari'ah, risiko rugi tetap ada. Itulah sebabnya, investor harus memperhatikan betul tingkat resiko masing - masing reksadana. Tingkat resiko dimaksud, tercermin dari komposisi portofolio setiap reksadana. Makin besar dana yang akan ditanamkan di ekuitas (pasar modal), resikonya makin tinggi. Kalau mau lebih aman, investor bisa memilih reksadana yang porsi ekuitas dengan pendapatan tetapnya nyaris sebanding. Faktor lain yang harus diperhatikan adalah prestasi atau kinerja reksadana dan repurtasi bagi si manajer investasi.

Reksadana syari'ah saat ini, minimal sudah ada tiga macam reksadana syari'ah. Dua diluncurkan PT

\footnotetext{
${ }^{13}$ Zainuddin Ali, Hukum Perbankan Syariah, (Jakarta: Sinar Grafika, 2010),
} hlm. 21. 
Danareka Investment Management, yakni Danareksa Syari'ah Berimbang (campuran) dan Danareksa Syari'ah (saham). Dua reksadana yang diluncurkan bulan juni 1997 yang telah berhasil menjaring dana lebih dari Rp. 20 miliar. Reksadana lainnya adalah Reksadana PNM Syari'ah yang dikelola PT PNM Invest Management. Awal Desember tahun 1997 sebuah reksadana syari'ah bernama Reksa Dana Rifan Syari'ah diluncurkan oleh Rifan Financindo Asset Management.

c. Pasar Uang dan Produk Perbankan Syari'ah

Pasar modal merupakan salah satu investasi yang dilakukan di pasar uang berdasarkan Sertifikat Waduah Bank Indonesia (SWBI). Untuk mengakses hal dimaksud, dapat dilakukan melalui reksadana syari'ah atau melalui tabungan dan/atau melalui deposito di bank syari'ah (Bank Muamalat Indonesia, Bank Syari'ah Mandiri, Bank IFI, dan BNI cabang Syari'ah). Keuntungan yang diperoleh penabung akan dihitung berdasarkan sistem bagi hasil. Namun, pada umumnya keuntungannya tidak besar, melainkan hanya sekitr 10\%saja.

d. Asumsi dan Dana Pensiun Syari'ah

Di Indonesia baru ada satu dana pensiun syari'ah, yaitu Dana Pensiun Syari'ah yang dikeluarkan PT. Pricipal Indonesia. Dana pensiun syari'ah dimaksud, mempunyai pola yang serupa dengan pola tabungan. Perusahaan yang menekuni asuransi syari'ah juga baru satu, PT Syarikat Takaful Indonesia yang memiliki dua anak perusahaan. Pertama, PT Asuransi Takaful Keluarga (produknya Takaful Dana Investasi, Dana Haji, Anak Asuh, Kesehatan, Al - Khairat, dan Kecelakaan Diri). Kedua, PT Asuransi Takaful Umum (Takaful Kebakaran, Kendaraan Bermotor, Rangka Kapal, dan Takaful Aneka).

e. Gadai Syari'ah

Gadai syar'iah ( $r a b n)$ adalah salah satu cara untuk memperoleh uang melalui kantor pegadaian syari'ah. Gadai syari'ah adalah menahan salah satu harta milik 
nasabah (rabin) sebagai barang jaminan (marbun) atas utang/pinjaman yang diperoleh dari kantor pegadaian syari'ah. Harta milik nasabah dimakdud, mempunyai nilai ekonomis. Dengan demikian, pihak yang menahan atau penerima gadai (murtabin) memperoleh jaminan untuk dapat mengambil kembali seluruh atau sebagian piutangnya. Produk gadai syari'ah, di antaranya : 1) pemberian pinjaman kepada warga masyarakat dengan menyerahkan harta benda sebagai jaminan, 2) pembiayaan pelayanan berupa jasa penaksiran atas nilai satu harta benda, dan 3) penitipan barang berupa sewa (ijarah). ${ }^{14}$

Pada sistem operasi bank syari'ah, pemilik dana menanamkan uangnya di bank tidak dengan motif mendapatkan bunga, tetapi dalam rangka mendapatkan keuntungan bagi hasil. Dana nasabah tersebut kemudian di salurkan kepada mereka yang membutuhkan (misalnya modal usaha) dengan perjanjian pembagian keuntungan sesuai kesepakatan.

Pembiayaan dalam perbankan syari'ah tidak bersifat menjual uang yang mengandalkan pendapatan bunga atas pokok pinjaman yang di investasikan, tetapi dari pembagian laba yang diperoleh pengusaha. Pendekatan bank syari'ah mirip dengan investment banking, di mana secara garis besar produk adalah mudarabah (trunst financing) dan musyarakah (partnership financing), sedangkan yang bersifat investasi diimplementasikan dalam bentuk murabahan (jual-beli). ${ }^{15}$

Secara garis besar, pengembangan produk bank syari'ah dikelompokkan menjadi tiga kelompok, yaitu:

1) Produk Penyaluran Dana

2) Produk penghimpunan Dana

3) Produk jasa

Produk-produk tersebut yang ditawarkan bank kepada nasabahnya. Dengan penjelasan sebagai berikut: ${ }^{16}$

${ }^{14}$ Ibid,. hlm. 22-23.

${ }^{15}$ Amir Machmud dan Rukmana, Bank Syariah (Teori, Kebijakan, dan Studi Empiris di Indonesia), (Jakarta: Erlangga, 2010), hlm. 28.

${ }^{16}$ Muhammad, Manajemen Dana Bank Syariah, (Jakarta: RajaGrafindo Persada, 2015), hlm. 28. 
1) Penyaluran Dana

a) Prinsip Jual Beli (Ba’i)

Jual beli dilaksanakan karena adanya pemindahan kepemilikan barang. Keuntungan bank disebutkan di depan dan termasuk harga dari harga yang dijual. Terdapat tiga jenis jual beli dalam pembiayaan konsumtif, modal kerja dan investasi dalam bank syariah, yaitu: Ba'i Al-Murabahah, Ba'i As-Salam, Ba'I Al-Istishna'.

b) Prinsip Sewa (Ijarah)

Ijarah adalah kesepakatan pemindahan hak guna atas barang atau jasa melalui sewa tanpa diikuti pemindahan kepemilikan atas barang yang disewa. Dalam hal ini bank menyewakan peralatan kepada nasabah dengan biaya yang telah ditetapkan secara pasti sebelumnya.

c) Prinsip Bagi Hasil (Syirkab)

Dalam prinsip bagi hasil terdapat dua macam produk, yaitu: Musyarakah dan Mudharabah.

2) Penghimpun Dana

a) Prinsip Wadiah

b) Prinsip Mudharabah

3) Jasa Perbankan

Pola konsumsi dan pola simpanan yang diajarkan oleh Islam memungkinkan umat Islam mempunyai kelebihan pendapatan yang harus diproduktifkan dalam bentuk investasi. Maka, bank Islam menawarkan tabungan investasi yang disebut simpanan mudarabah (simpanan bagi hasil atas usaha bank). Untuk dapat menghasilkan usaha bank kepada penyimpan mudarabah, bank syari'ah menawarkan jasa-jasa perbankan kepada masyarakat dalam bentuk berikut:

(a) Pembiayaan untuk berbagai kegiatan investasi atas dasar bagi hasil terdiri dari: (1) pembiayaan investasi bagi hasil al mudarabab; dan (2)pembiayaan investasi bagi hasil al musyarakah. Dari pembiayaan investasi tersebut, bank akan memperoleh pendapatan berupa 
bagi hasil usaha.

(b) Pembiayaan untuk berbagai kegiatan perdagangan terdiri dari: (1) pembiayaan perdagangan al-mudarabah; dan (2) pembiayaan perdagangan al-baiu bithaman ajil. Dari pembiayaan perdagangan tersebut, bank akan memperoleh pendapatan berupa mark-up atau margin keuntungan.

(c) Pembiayaan pengadaan barang untuk disewakan atau untuk disewa belikan dalam bentuk: (1) sewa guna usaha atau disebut al-ijarab; (2) sewa beli atau disebut bain takjiri. Di Indonesia, al ijaroh dan bain takjiri tidak dapat dilakukan oleh bank. Namun demikian, penyewaan fasilitas tempat penyimpanan harta dapat dikategorikan sebagai al-ijaroh. Dari kegiatan usaha al-ijaroh, bank akan memperoleh pendapatan berupa sewa.

(d) Pemberian pinjaman tunai untuk kebajikan (al-qardhul hasan) tanpa dikenakan biaya apapun kecuali biaya administrasi berupa segala biaya yang diperlukan untuk sahnya perjanjian utang, seperti bea materai, bea akta notaries, bea studi kelayakan, dan sebagainya. Dari pemberian pinjaman al-qardhul hasan, bank akan menerima kembali biaya-biaya administrasi.

(e) Fasilitas-fasilitas perbankan umumnya yang tidak bertentangan dengan syari'ah seperti penitipan dana dalam rekening lancar (current account), dalam bentuk giro wadi'ah yang diberi bonus dan jasa lainnya untuk memperoleh balas jasa (fee) seperti: pemberian jaminan (al-kafalah) pengalihan tagihan (al-hiwalab), pelayanan khusus (al-jualab), pembukaan L/C (al-wakalab), dan lain-lain. Dari pemakaian fasilitas-fasilitas tersebut bank akan memperoleh pendapatan berupa fee. ${ }^{17}$

Dalam bentuk praktek dilapangan, di sampingmenyediakan modal yang dibutuhkan masyarakat kecil untuk membeli barang-

${ }^{17}$ Amir Machmud dan Rukmana, Bank Syariah (Teori, Kebijakan, dan Studi Empiris di Indonesia, (Jakarta: Erlangga, 2010), hlm. 28-29. 
barang modal (alat kerja), modal kerja operasional, dan faktor lain yang dibutuhkan untuk membangun satu unit bisnis kecil, bank syari'ah idealnya juga harus memberikan pendampingan manajerial, seperti aspek pemasaran keuangan dan produksi bahkan sampai memfasilitasi jaringan pemasaran (tata niaga) yang lebih efisien yang menguntungkan usaha kecil menengah. Dengan demikian, bank syari'ah menjadi partner usaha dalam lingkup yang lebih luas dan terintegrasi.

Konsep ideal perbankan yang sesuai dengan syari'ah Islam seperti yang diuraikan di atas pada prakteknya belum diselenggarakan secara ideal pula oleh bank-bank Islam di Indonesia. Menurut Zainul Arifin, beberapa praktek perbankan syari'ah yang masih jauh dari konsep ideal bank syari'ah adalah:

a) Terlalu memusatkan pada mekanisme murabahah dan mengabaikan mekanisme pembiayaan sah lainnya;

b) Menerapkan tingkat bunga untuk margin keuntungan tetap dalam mekanisme murabahab;

c) Mengabaikan aspek-aspek sosial dalam pembiayaan;

d) Kurang memberi respon tambah pada kebutuhankebutuhan pembiayaan pemerintah;

e) Kegagalan bank-bank Islam dalam menjalin kerjasama di antara mereka.

Sistem keuangan adalah aturan yang menyangkut aspek keuangan. Dalam sistem perbankan di Negara-negara sedang berkembang, sistem keuangan telah menjadi instrumen penting dalam melancarkan kegiatan pembangunan. Keberadaannya dalam berbagai aspek usaha masyarakat luas telah memberikan pertanda bahwa prinsip-prinsip Islam sangat aplikatif dalam dunia bisnis modern. Namun demikian, implementasi perbankan syari'ah terkadang masih mengalami kendala, baik dari lembaga itu sendiri, maupun dari pemerintah dan masyarakat. Untuk itu, diperlukan kesungguhan dari berbagai pihak untuk memperbaiki kekurangan yang ada menuju sistem perbankan syari'ah yang rahmatan lil alamin. ${ }^{18}$

Khususnya pada pembiayaan mudharabah dan musyarakah,

${ }^{18}$ Ibid., hlm. 29. 
bank syari'ah akan melakukan pengawasan dan pembinaan perkembangan proyek usaha yang dikelola oleh nasabah lebih ketat, karena keuntungan yang akan diperoleh bank syari'ah berasal dari keuntungan yang dibagi hasilkan berdasarkan nisbah yang telah disepakati bersama dari usaha yang dikelola oleh nasabah sehingga jika usaha yang kelola oleh nasabah tersebut gagal maka bank syari'ah harus memikul resiko kehilangan dana yang telah diberikan kepada nasabah.

Pada jangka waktu (masa) pembiayaan tidak mustahil terjadi suatu kondisi pembiayaan, yaitu adanya suatu penyimpangan utama dalam hal pembayaran yang menyebabkan keterlambatan dalam pembayaran atau diperlukan tindakan yuridis dalam pengembalian atau kemungkinan potensi losss. Kondisi ini yang disebut dengan pembiayaan bermasalah, keadaan turunnya mutu pembiayaan tidak terjadi secara tiba-tiba, tetapi selalu memberikan "warning sign" atau faktor-faktor penyebab terlebih dahulu dalam masa pembiayaan. Ada beberapa faktor penyebab pembiayaan bermasalah sebagai berikut:

a). Faktor intern (berasal dari pihak bank).

(1) Kurang baiknya pemahaman atas bisnis nasabah.

(2) Kurang dilakukan evaluasi keuangan nasabah.

(3) Kesalahan setting fasilitas pembiayaan (berpeluang melakukan side streming).

(4) Perhitungan modal kerja tidak didasarkan kepada bisnis usaha nasabah.

(5) Proyeksi penjualan terlalu optimis.

(6) Proyeksi penjualan tidak memperhitungkan kebiasaan bisnis dan kurang memperhitungkan aspek competitor.

(7) Aspek jaminan tidak diperhitungkan aspek marketable.

(8) Lemahnya supervise dan monitoring.

(9) Terjadinya erosi mental: kondisi ini dipengaruhi timbal balik antara nasabah dengan pejabat bank sehingga mengakibatkan proses pemberian pembiayaan tidak didasarkan pada praktek 
perbankan yang sehat. ${ }^{19}$

b) Faktor ekstern (berasal dari pihak luar)

(1) Karakter nasabah tidak amanah (tidak jujur dalam memberikan informasi dan laporan tentang kegiatannya).

(2) Melakukan sidestreaming penggunaan dana.

(3) Kemampuan pengelolaan nasabah tidak memadai sehingga kalah dalam persaingan usaha.

(4) Usaha yang dijalankan relatif baru.

(5) Bidang usaha nasabah telah jenuh.

(6) Tidak mampu menanggulangi nasabah/kurang menguasai bisnis.

(7) Meninggalkan key person.

(8) Perselisihan sesama direksi

(9) Terjadi bencana alam.

(10) Adanya kebijakan pemerintah: peraturan suatu produk atau sektor ekonomi atau industri dapat berdampak positif maupun negatif bagi perusahaan yang berkaitan dengan industri tersebut. ${ }^{20}$

\section{Prinsip Operasional Bank Syari'ah}

Dalam operasionalnya, Bank Syari'ah mengacu kepada prinsip bagi hasil sebagaimana ditentukan dalam Peraturan Pemerintah No 72 tahun 1992 yang menjelaskan bahwa:

a. Untuk dapat meningkatkan layanan jasa perbankan kepada masyarakat perlu dikembangkan kegiatan usaha bank yang dapat memenuhi kebutuhan masyarakat.

b. Penyedia jasa perbankan berdasarkan prinsip bagi hasil merupakan pelayanan jasa perbankan yang dibutuhkan masyarakat.

c. Berhubung dengan hal itu dipandang perlu untuk mengatur kegiatan usaha bank berdasarkan prinsip bagi

${ }^{19}$ Trisadini P. Usanti, Abd. Shomad, Transaksi Bank Syariah, (Jakarta: Bumi Aksara, 2013), hlm. 101-102.

${ }^{20}$ Ibid., hlm. 102-103. 
hasil dalam peraturan pemerintah. ${ }^{21}$

Secara umum, setiap bank Islam dalam menjalankan usahanya minimal mempunyai lima prinsip operasional, yaitu sebagai berikut:

1) Prinsip simpanan giro, yaitu fasilitas yang diberikan oleh bank untuk memberikan kesempatan kepada pihak yang kelebihan dana untuk menyimpan dananya dalam bentuk al wadiah, yang diberikan untuk tujuan keamanan dan pemindahan buku, bukan untuk tujuan investasi guna mendapatkan keuntungan seperti halnya tabungan atau deposito.

2) Prinsip bagi hasil, yaitu meliputi tata cara pembagian hasil usaha antara pemilik dana (shohibul mal) dan pengelola dana (mudarib). Pembagian hasil usaha ini dapat terjadi antara bank dengan penyimpan dana maupun antara bank dengan nasabah penerima dana. Prinsip ini dapat digunakan sebagai dasar untuk produksi pendanaan (tabungan dan deposito) maupun pembiayaan.

3) Prinsip jual beli dan mark-up, yaitu pembiayaan bank yang diperhitungkan secara lump-sum dalam bentuk nominal di atas nilai kredit yang diterima nasabah penerima kredit dari bank. Biaya bank tersebut ditetapkan sesuai dengan kesepakatan antara bank dan nasabah.

4) Prinsip sewa, terdiri dari dua macam, yaitu sewa murni (opening lease/ijarob) dan sewa beli (financial lease/bai' al tajir).

5) Prinsip jasa (fee), meliputi seluruh kekayaan nonpembiayaan yang diberikan bank, seperti kliring, inkaso, transfer, dan sebagainya. ${ }^{22}$

\section{Tantangan Pengembangan Sistem Perbankan Syari'ah}

Sebelum mengemukakan tantangan pengembangan

${ }^{21}$ Nurul Hak, Ekonomi Islam, Hukum Bisnis Syariah Mengupas Ekonomi Islam, Bank Islam, Bunga Uang dan Bagi Hasil, Wakaf Uang dan Sengketa Ekonomi Syariah), (Yogyakarta: Teras, 2011), hlm. 24-25.

${ }^{22}$ Amir Machmud dan Rukmana, Bank Syariah (Teori, Kebijakan, dan Studi Empiris di Indonesia, (Jakarta: Erlangga, 2010), hlm. 27-28. 
sistem perbankan syari'ah, penulis perlu mengemukakan beberapa hal. Pertama, perbankan syari'ah memiliki daya tahan yang relatif lebih kuat dalam menghadapi krisis ekonomi dan moneter di tahun 1998 sampai dengan tahun 2000-an. Fakta hukum dimaksud, menunjukan bahwa dalam periode krisis ekonomi perbankan syari'ah diharapkan dapat berperan lebih besar dalam proses pemulihan perekonomian di Indonesia yang masih terus berlangsung dan masih terasa sampai tahun 2007. Kedua, nilai - nilai syari'ah dalam perspektif mikro dan makro dapat menentukan perkembangan Bank Syari'ah dan lembaga keuangan syari'ah lainnya. Oleh karena itu, nilai - nilai mikro dimaksud, mengandung makna sebagai berikut ${ }^{23}$

a. Nilai-nilai yang bersifat mikro

b. Nilai-nilai yang bersifat makro

c. Kerangka dan perangkat pengaturan perbankan syari'ah yang belum lengkap

d. Cakupan pasar masih terbatas

e. Kurang pemahaman produk dan jasa perbankan syari'ah

f. Institusi pendukung belum lengkap dan efektif

g. Skim pembiayaan bagi hasil perlu ditingkatkan

h. Pemenuhan standar keuangan syari'ah

\section{UMKM (Usaha Mikro Kecil dan Menengah)}

Peningkatan UMKM telah menunjukkan perkembangan yang terus meningkat dan bahkan mampu menjadi penopang pertumbuhan ekonomi nasional. Hal tersebut dapat dilihat dari data BPS 2010, yang menunjukkan populasi UMKM mencapai sekitar 51,3 juta unit usaha atau kontribusi sebesar 99\% dari keseluruhan pelaku bisnis di Indonesia. UMKM juga mampu menyerap tenaga kerja sebesar Rp 2.609 triliun atau 55,6\%. ${ }^{24}$ Dari data tersebut perkembangan UMKM dapat dikatakan cukup baik dan masih memiliki prospek yang baik untuk ditingkatkan, mengingat proses restrukturisasi sektor korporat dan BUMN

${ }^{23}$ Zainuddin Ali, Hukum Perbankan Syariah, (Jakarta: Sinar Grafika, 2010), hlm. 79-80.

${ }^{24}$ http://cetak.kompas.com. 
berlangsung lamban, padahal permintaan barang dan jasa yang selama ini dipenuhi sektor korporat terus meningkat, hal ini memberikan peluang bisnis bagi UMKM dalam berbagai sektor ekonomi. Pertumbuhan dan peran UMKM masih bisa terus ditingkatkan, tidak saja karena ketangguhannya dalam menghadapi berbagai perubahan ekonomi, tetapi juga kemampuannya yang besar dalam menyediakan lapangan kerja, serta mengatasi kemiskinan. Untuk menjamin optimisme perkembangan UMKM dimasa depan, jelas memerlukan penguatan adanya modal dan peran pembiayaan khususnya perbankan atau lembaga non bank lainnya untuk mendukungnya. Telah kita ketahui bahwa dalam mengembangkan usahanya UMKM menghadapi berbagai kendala baik yang bersifat internal maupun eksternal. Permasalahan tersebut diantaranya adalah permasalahan modal yang selalu menjadi kebutuhan pokok bagi UMKM..$^{25}$

\section{Simpulan}

Berdasarkan pembahasan di atas dapat di simpulkan bahwa: produk kegiatan usaha perbankan syari'ah dalam mengembangkan UMKM dibutuhkan upaya keras dari perbankan syari'ah Indonesia dalam menghadapi Masyarakat Ekonomi ASEAN (MEA). Persepsi mengenai pengetahuan dan pemahaman terhadap produk dan jasa perbankan syari'ah menunjukkan adanya kesenjangan antara kebutuhan akan jasa keuangan yang sesuai dengan prinsip syari'ah dengan pengetahuan mengenai jenisjenis produk serta operasional sistem perbankan syari'ah yang benar. untuk menghadapi berbagai tantangan atas terlaksananya Masyarakat Ekonomi ASEAN (MEA), maka perbankan syari'ah Indonesia harus mampu dan yakin dalam menjalankan berbagai strategi pengembangan. Untuk itu, peran semua pihak dalam pengembangan perbankan syari'ah Indonesia diharapkan mampu menjadikan perbankan syariah Indonesia memiliki prospek yang baik, semakin berkualitas dan mampu bersaing dengan negara-

\footnotetext{
${ }^{25}$ Sri Lestari Hs, Jurnal Perkembangan dan Strategi Pengembangan Pembiayaan Usaba Mikro Kecil dan Menengah, http://www. Jurnalperkembangan dan pengembangan pembiayaan.com.
} 
negara ASEAN dalam menghadapi ekonomi pasar global Masyarakat Ekonomi ASEAN (MEA) 2015. 


\section{DAFTAR PUSTAKA}

Adiwarman A. Karim, Ekonomi Islam (Suatu KAjian Kontemporer), Jakarta: Gema Insani, 2007.

Amir Machmud dan Rukmana, Bank Syariah (Teori, Kebijakan, dan Studi Empiris di Indonesia, Jakarta: Erlangga, 2010.

Heri Sudarsono, Bank dan Lembaga Keuangan Syari'ah (Deskripsi dan Ilustrasi), Yogyakarta: Ekonisia, 2013.

Kasmir, Bank \& Lembaga Keuangan Lainnya, Jakarta: PT. RajaGrafindo Persada, 2002.

Muhammad, Manajemen Dana Bank Syariah, Jakarta: PT. Raja Grafindo Persada, 2015.

Nurul Hak, Ekonomi Islam, Hukum Bisnis Syariah (Mengupas Ekonomi Islam, Bank Islam, Bunga Uang dan Bagi Hasil, Wakaf Uang dan Sengketa Ekonomi Syariah), Yogyakarta: Teras, 2011.

Nevi Hesnita, "Politik Hukum Ekonomi Syari'ah di Indonesia”, Jurnal, IAIN Ar-Raniry, 2012.

Sri Lestari Hs, Jurnal Perkembangan dan Strategi Pengembangan Pembiayaan Usaha Mikro Kecil dan Menengah, http://www. Jurnalperkembangandanpengembanganpembiayaan.com.

Trisadini P. Usanti, Abd. Shomad, Transaksi Bank Syariah, Jakarta: Bumi Aksara, 2013.

Zainuddin Ali, Hukum Perbankan Syariah, Jakarta: Sinar Grafika, 2010. 
